\title{
Models of Financing and Available Financial Resources for Transport Infrastructure Projects
}

\author{
O. Pokorná, D. Mocková
}

\begin{abstract}
A typical feature of transport infrastructure projects is that they are expensive and take a long time to construct. Transport infrastructure financing has traditionally lain in the public domain. A tightening of many countries' budgets in recent times has led to an exploration of alternative resources for financing transport infrastructures. A variety of models and methods can be used in transport infrastructure project financing. The selection of the appropriate model should be done taking into account not only financial resources but also the distribution of construction and operating risks and the contractual relations between the stakeholders.
\end{abstract}

Keywords: transport infrastructure, project financing, financial resources, models of financing, investments, PPP (Public - Private Partnership)

\section{Financing of transport investments}

From the commercial point of view most transport investments are part of a broader category known as project financing. A project's viability is therefore closely connected with the valorization of the future cash flow generated by the project.

There are some features specific to infrastructure project financing that make the availability of resources more difficult. These are an infrastructure project's:

- long life-cycle

- relatively low operating costs

- need for large capacity resources

- long construction period (2-7 years)

As regards the cash-flow this means:

- Negative cash flow throughout the construction period, which is usually longer than in the case of ordinary industrial projects. This is an important factor in the risk to the investor.

- Slow increase in the cash flow at the beginning of operation, caused by large interest payments on loans.

- High cash flow after amortization.

A typical feature of transport infrastructure projects is that they are expensive and take a long time to construct. This is caused partly by the nature of the projects themselves and partly by the fact that they aim to meet a future demand. This represents a long-term tying up of large resources, while the regularity and the level of the revenue remain uncertain.

Transport infrastructure financing has traditionally lain in the public domain.

By its nature society should itself maintain the quality and quantity of its infrastructures according to present and future developments. Given that infrastructures of the individual transport modes are interconnected in the integrated transport infrastructure of a country, it is obvious that the transport infrastructure should be managed comprehensively and should be subject to a centralized investment and development regime.

A tightening of many countries' budgets in recent times has led to the exploration of alternative resources for financ- ing the transport infrastructure. Tax revenues are insufficient to maintain the capital necessary for the development of the transport infrastructure. Therefore it is desirable and natural to allow private investors to enter the market or to let users pay for their "consumption". In view of the long duration of many projects, there arises the problem of generating cash flow that will be sufficient to ensure debt servicing and an appropriate return on the capital invested.

\section{Available financial resources}

Finance resources for transport infrastructure projects can be divided into public and alternative.

These can then be divided as follows:

- Public resources

- State budget

$\square$ State transport infrastructure fund

$\square$ Other government subsidies and grants

- Non-budget public resources

$\square$ External subsidy funds and programmes (e.g. Phare, ISPA)

- Other - Alternative resources

$\bullet$ Loans

$\square$ from domestic banks

$\square$ from foreign commercial banks

$\square$ from export credit institutions

$\checkmark$ from international financial institutions

- Entry to capital markets

$\square$ Bond issue programmes

$\square$ Stock issue programmes

- Leasing

$\checkmark$ Guarantees, bills

- Fee and toll collecting - user pays

- Subsidiary company purchasing

- Project financing via Public-Private Partnership mixed scenarios for private capital involvement

\section{Models of financing}

Transport infrastructure project financing can use a variety of models and methods. The selection of the 
Table 1: Model types of infrastructure construction financing

\begin{tabular}{|c|c|c|c|c|c|}
\hline \multirow{2}{*}{ Type } & \multicolumn{2}{|c|}{ Financing } & \multicolumn{2}{c|}{ Risk bearer } & \multirow{2}{*}{ Promoter } \\
\cline { 2 - 5 } & Private & Public & Construction & Operation & \\
\hline $\mathbf{1}$ & Yes & No & Private sector & Private sector & Private sector \\
\hline $\mathbf{2}$ & Yes & No & Private sector & Public sector & Private sector \\
\hline $\mathbf{3}$ & Yes & No & Private sector & Private sector & Public sector \\
\hline $\mathbf{4}$ & Yes & No & Public sector & Public sector & Public sector \\
\hline $\mathbf{5}$ & Sometimes & Yes & Public sector & Public sector & Public sector \\
\hline
\end{tabular}

appropriate model should take into account not only financial resources but also the distribution of construction and operating risks and the contractual relations between the stakeholders.

Following from the above, five main financial models can be stated:

Type 1: Fully financed by private capital. Financial resources, structure owner, its management and operation are purely private. This solution is feasible only in cases where the project is able to generate revenue to cover debt servicing and provide a reasonable economic return on the capital. Therefore only a quickly profit-making project can be taken into consideration.

Type 2: Investment is financed by private capital; a private company builds the structure. The public sector may be partially involved in operation (for example in a regulatory role) defending the public interest and property. Otherwise, this type may be viewed as a modification of type 1 .

Type 3: The role of the promoter is performed by the public sector, but the financial resources are purely private. The structure is managed by the private sector entity, as well as the operation of the facility. State guarantees may be provided.

Type 4: The promoter of the project is a public sector entity, which also manages the structure and the operation, bearing the risk and other liabilities. The financing may use private resources.

Type 5: The project is operated and constructed by the public sector. The financial resources are provided mainly by public funds and other subsidies and by fee and toll collection. Debt service may be partially borne by the infrastructure user in the form of fees and tolls.

There are many other possible solutions that can combine the above types. Many different financing techniques may be involved.

\section{Project financing with private capital participation}

In the past few years private sector participation and involvement in development and financing of infrastructure projects has increased noticeably, ranging from management contracts to entirely new projects.

Some key factors contributing to this development have been:

1) Governments recognized that they did not have sufficient means available to innovate, maintain and build infrastructures to match the expected and required economic growth;

2) A broad range of opinion holds that the private sector would in some cases be more effective than the public sector.

Nevertheless, transport infrastructure investments are not a very attractive form for the private sector, for a number of reasons:

- Excessively long amortization period

- A long period between project commencement and the first revenues

- The money is inextricably tied up in the structure

- No possibility for innovation, the product is a given constant

- Threat of political changes

Due to these considerations, reduced interest from investors may be encountered. Private capital may be obtained by providing long-term state guarantees. These can take the following forms:

- Revenue guarantees

- Loss diminution

- Purchase volume guarantees by the state

- Set disbursement coverage

- Settlement of expenses and purchases of certain equipment

- Awarding other concessions for profit - making services as compensation

Investing private resources through the use of governmental guarantees brings advantages to both sides. The investor is confident of a return on the invested capital and at the same time the public sector gains new opportunities to invest while not increasing strains on the budget. This shows a way to avoid budgetary restrictions.

There are many forms of private sector participation in the transport sector. The following could be suitable for infrastructure investments: 
- Joint venture - a company with joint involvement is set up, with public and private sector liability shared in the fields of financing, construction and operation

- Full privatisation

- Operations, concessions and management contracts - the private sector is in charge of operations and is remunerated through profit sharing or direct payments by the government

- BOOT contracts (Build, Own, Operate, Transfer) - the private sector bears full responsibility for financing, construction and operation for a set period, which matches the repayment of debts and an appropriate return of the investment. After this period the infrastructure is transferred into public ownership in accordance with the contractual arrangements. This is probably the most commonly used form of private participation in infrastructure. There are many variations on this contract, which are listed below.

- BOO contracts (Build, Own, Operate) - the private sector retains ownership and further operation

- BFSR contracts (Build, Finance, Share revenue)

- ROT contracts (Rehabilitate, Operate, Transfer)

- BLT contracts (Build, Lease, Transfer)

- BTO contracts (Build, Transfer, Operate)

- Other PPP variations

As mentioned, there are many other variations, which are distinguished mainly by the allocation of risk between the contractors.

An essential fact of private financing is that all costs are borne by the final user. Cash flow is generated by collecting tolls (or a similar fee that is obvious to the user). The tolls and fees collected must cover the operation cost, debt service and return on equity.

Project financing is usually used for large and expensive constructions with long-term duration, where a longer period is required to amortize the investments and to generate the required revenue. The distribution of creditors depends on the cash flow generated without being linked to the property of the project promoters. Accordingly, the bank as a creditor has a restricted possibility of recourse.

The basic project financing features are:

- "A special Purpose Vehicle" (SPV) is established, which becomes a promoter of the project. The purpose is to separate the project from other activities of the participants. This should ensure transparency of financing. This isolation enables the use of "off-balance financing", so the project does not affect the balance sheet of its sponsors. The debtor is the SPV. The sponsor's balance sheet contains only its involvement, but not the total debt.

- A close link between debt repayment and the project's future cash flow, which is estimated according to technical and project analysis (proving that future cash flow will be sufficient to cover debt repayment including interest).

- Risk allocation between more than one participant is essential due to the large extent of the project. One subject can hardly be strong enough to cover and take on the whole risk. Therefore risks are divided according to the contract over the many subjects involved, mainly sponsors and banks; but also other participants, e. g. suppliers, operators, public bodies and insurance companies.

The way of allocating risk differs case by case, and the contract should accurately stipulate its type and extent.

\section{Conclusion}

The field of transport infrastructure construction and its financing is the focus of repeated political and pragmatic discussions. The level of investments in transport infrastructure is within the sphere of an ordinary citizen's concern, as it results from the nature of infrastructure. The development of infrastructure and the resulting investments are issues of interest for each state, and constitute a basis for its economic progress. Other infrastructure features, which cause a tying up of financial potential, similarly should not be neglected. One of these features is the long-term nature of infrastructure investments. The construction time horizon in this field usually exceeds 20 years, with the unavailability of ordinary commercial credit banking.

These days European countries are desperately looking for ways how to involve private capital in the process of infrastructure financing. The countries are focusing on the process of creating an environment suitable for Public Private Partnerships.

Interested parties aim to create an optimum financial model, which will determine the roles of individual stakeholders and determine the extent of their participation in the project's management, monitoring, risk sharing and last but not least the total of their financial contribution and resultant profit-sharing. The form and the size of an investor's participation are related to the period and extent of the return on investment. A precondition for the successful start of a PPP is therefore the positive efficiency of the project and a reasonable return on investments.

\section{References}

[1] Estache, A., Strong, J.: The Rise, the Fall, and ... the Emerging Recovery of Project Finance in Transport. World Bank Institute

[2] Kay, J.: Efficiency and Private Capital in the Provision of Infrastructure. Infrastructure Policies for the 1990's, Paris, OECD, 1993, pp. 58-71

[3] Kolektiv pracovníků Dopravní fakulty ČVUT: Alternatiuni možnosti financování železničnich koridori̊. ČVUT, Praha, 1998

[4] Pokorná, O.: Diplomová práce - Zdroje financováni dopravni infrastruktury. Praha, 2001

Ing. Denisa Mocková

e-mail:mockova@fd.cvut.cz

phone: +420224359160

fax: +420224919017

Ing. Olga Pokorná

e-mail: pokorna@mdcr.cz

phone: +420251431059

Czech Technical University in Prague

Faculty of Transportation Sciences

Horská 3,

12803 Praha 2, Czech Republic 